\title{
Analysis and Modelling of Ship Manoeuvring Simulation in Landslide-Generated Waves
}

\author{
Peiyin Yuan $\mathbb{D D}^{1}$ and Yu Zhao $\mathbb{D}^{2,3}$ \\ ${ }^{1}$ College of Shipping and Naval Architecture, Chongqing Jiaotong University, Chongqing 400074, China \\ ${ }^{2}$ College of River and Ocean Engineering, Chongqing Jiaotong University, Chongqing 400074, China \\ ${ }^{3}$ College of Architecture and Urban Planning, Chongqing Jiaotong University, Chongqing 400074, China \\ Correspondence should be addressed to Peiyin Yuan; yuan_pei_yin@163.com
}

Received 26 October 2021; Revised 24 November 2021; Accepted 3 December 2021; Published 18 December 2021

Academic Editor: Qizhou Hu

Copyright ( 92021 Peiyin Yuan and Yu Zhao. This is an open access article distributed under the Creative Commons Attribution License, which permits unrestricted use, distribution, and reproduction in any medium, provided the original work is properly cited.

\begin{abstract}
The geological conditions of the Three Gorges Reservoir Region are complex and changing, and large- and medium-sized landslides are widely distributed. When a high-speed moving landslide enters the water, the water is significantly disturbed, and a landslide-generated wave will be formed, which will spread along the upstream and downstream of the river, causing significant threats and destruction to the hydraulic structures and the navigation of ships. Based on the typical rock landslide parameters and fracture development, we establish a three-dimensional physics experimental model of the bending section of the landslidegenerated wave in the Three Gorges Reservoir Region. This paper primarily studies the variation law of the first wave height of landslide-generated waves with the width, height, and water entry velocity of the landslide body and then provides an empirical formula for the first wave height of landslide-generated waves in the curved section of the Three Gorges Reservoir Region. The ship rolling motion equation in the landslide-generated water area is analysed and established systematically. Additionally, the ship manoeuvring motion model in the landslide-generated water area is built. This paper explains the variation characteristics of ship turning tracks at different sailing speeds and sailing positions and proposes a basis to determine the navigation safety of ships in this area, thus providing new theoretical and technical support for the risk assessment of navigation of ships in the reservoir area.
\end{abstract}

\section{Introduction}

With the rapid development of the economy, ships have gradually become large-scale and standardised. The navigational safety of ships has attracted much interest; in particular, the fluctuation of the water level in the Three Gorges Reservoir Region causes the bank slope to become unstable and slide down at high speed, thus forming a landslide-generated wave, which poses a significant threat to the hydraulic structure in the river course, coastal construction, and navigation safety of ships.

Scholars have studied the characteristics of landslideinduced waves using simulation models and model tests. Duc et al. [1] performed a combined computer simulation of landslide motion and its impulse and demonstrated that rainfall with a high intensity in a short period was the triggering factor of the landslide. Ersoy et al. [2] used a 3D numerical analysis to study the potential generation of impulse waves, using the data of paleo-landslides at the Artvin Dam reservoir. Hsiao et al. [3] developed a meshless numerical model for simulating tsunamis generated by submerged landslides. Karahan et al. [4] evaluated the potential landslide area of impulse waves using 3D numerical simulation-based models for the Tersun Dam reservoir. Shih et al. [5] investigated the formation and attenuation characteristics of landslide tsunamis using hydraulic model tests. Kim et al. [6] demonstrated that subaerial landslides generate highly nonlinear waves with complex wave patterns and runup. Bullard et al. [7] used four different slide volumes to achieve a wide range of dimensionless landslide parameter values. Takabatake et al. [8] investigated three types of landslide-generated tsunamis through laboratory 
experiments and revealed that the characteristics of the leading-wave decay and the trailing waves were enhanced.

Scholars have established a ship manoeuvring motion method and have analysed ship manoeuvring motion characteristics. Chillcce and Moctar [9] established a numerical method to simulate ship manoeuvring in waves and solved the six-degree-of-freedom nonlinear equations of the motion described. Taimuri et al. [10] presented a modular mathematical model and a reference technique for the rapid estimation of manoeuvring trajectories and motion time histories of single- and twin-screw propulsion ships. Hasnan et al. [11] researched the turning test results of ships with a rudder angle in short-crested irregular waves using ship models of a tanker and a container ship. Seo and Kim [12] performed a numerical analysis of ship manoeuvring performance in the presence of incident waves and resultant ship motion responses and solved the wave-body interaction problem using ship slip speed and rotation. Carthen et al. [13] conceived the modified manoeuvring mathematical group (MMG) model to predict the manoeuvring motions of a ship and defined a generalised prediction method to analyse the flow pattern around the gate rudder. Yasukawa and Yoshimura [14] introduced an MMG standard method composed of four elements. Suzuki et al. [15] assessed the manoeuvring limit in adverse weather by comparing the data of the timeaveraged values of the longitudinal ship speed.

This paper is based on a physical test to analyse the characteristics of landslide-induced waves and derives the equations of ship motion in an area of a landslide-induced wave. In addition, a ship manoeuvring motion model in the landslide-generated water area is built. The model facilitates a rapid forecast of the hazards from landslide-induced waves in reservoirs and provides a reference for modelling other types of physical tests.

\section{Model Test}

A hydraulic model test must simultaneously satisfy the geometric similarity, kinematic similarity, and dynamic similarity. In this study, the model test first determined the size of the test model and then determined other properties. The model scale was $1: 70$, and the scale of other characteristic values was determined according to the Froude similitude criterion.

2.1. Layout of Model Test. The model test used a curved canyon reservoir as the research object. Based on the model scale of $1: 70$, the centre front length of the river was $48 \mathrm{~m}$, the upstream river was $28 \mathrm{~m}$, the radius of curvature at the bend was $7 \mathrm{~m}$, and the length of the downstream river was $13 \mathrm{~m}$. The cross section of the river was trapezoidal, the top width was $8 \mathrm{~m}$, the bottom width was $2.94 \mathrm{~m}$, and the depth of the river was $1.6 \mathrm{~m}$. The slope angles on the left and right sides of the river were $33^{\circ}$ and $20^{\circ}$. The landslide-generated generator was set at the entrance of the bend on the left side of the river. The arrangement of the instruments and measuring points is shown in Figure 1.

2.2. Chute and Landslide. Rock landslides are caused by rock mass failures. Rock landslides in the Three Gorges Reservoir Region are primarily composed of sandstone and mudstone. In the experiment, cement and gravel were used as rigid block materials, and the average densities of natural mudstone and sandstone were selected. According to the law of rock mass fracture distribution, rigid blocks of different sizes were arranged and combined to form a model landslide. During the test, the length of the landslide was $1 \mathrm{~m}$. The shape and volume of the landslide were changed by combining its width and thickness.

The chute was composed of a steel bottom plate and a wing plate with a length of $2 \mathrm{~m}$ and width of $1.6 \mathrm{~m}$. The angle of the chute could be adjusted from $0^{\circ}$ to $80^{\circ}$. When the gate opened, the slide left the chute and accelerated toward the water surface due to gravity. The landslide initially slid as one piece. With an increase in the sliding distance, the sliding body gradually became a debris block under the action of the friction force of the bottom plate and wing plate. The landslide generator is shown in Figure 2.

Based on the principle of sediment grain size, the rock fracture spacing was discrete in the horizontal, longitudinal, and vertical directions. With a scale model of $1: 70$, five groups of dimensions $\mathrm{D}_{100}, \mathrm{D}_{80}, \mathrm{D}_{60}, \mathrm{D}_{40}$, and $\mathrm{D}_{10}$ were selected as the geometric characteristics of rigid blocks. The specific sizes of the rigid blocks combined in the model test are shown in Table 1.

2.3. River. The river channel was designed at a scale of $1: 70$. The length of the centreline of the flume was $48 \mathrm{~m}$. The length of the upstream section was $28 \mathrm{~m}$, and the radius of the bending section was $7 \mathrm{~m}$. The length of the downstream reaches was $13 \mathrm{~m}$. The cross section of the flume was trapezoidal with a top width of $8 \mathrm{~m}$ and bottom width of $2.94 \mathrm{~m}$. The river was $1.6 \mathrm{~m}$ deep. The landslide-generated wave generating device was arranged in a curved section of the river course. Self-propelled vessels travelled from upstream to downstream of the river course. High-speed cameras, measuring bridges, and other test equipment were placed above the river. The river channel model is shown in Figure 3.

2.4. Measuring Equipment. During the experiment, an ultrasonic wave acquisition analyser was used to measure the characteristics of the landslide-generated wave after the landslide entered the water. All the experiments were recorded at the same image-acquisition frequency. The collection time of the experiment was $50 \mathrm{~s}$, the sampling frequency was $50 \mathrm{~Hz}$, and the accuracy of the water level measurement was $0.1 \mathrm{~mm}$. The test was connected through three 16-channel sensor signals, the measuring range was $500 \mathrm{~mm}$, and a total of 48 monitoring points were set up to monitor the variation characteristics of the landslide-generated waves. 


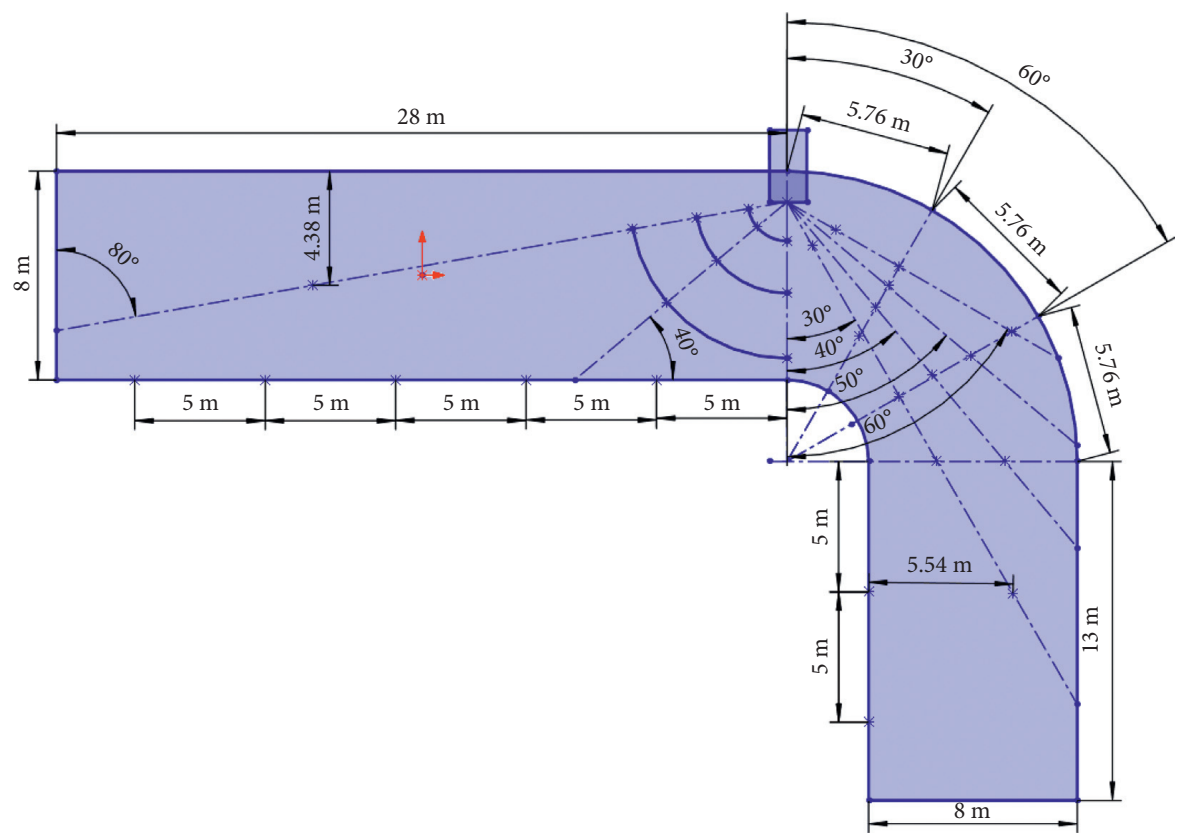

FIgURE 1: Layout of model test.

\section{Height of the First Wave of the Landslide- Generated Wave}

Impulse waves are formed by a rapid or impulsive transfer of momentum from a mass flow to a water body. The wave generator was the landslide. The landslide may be considered a moving object, causing a disturbance in the water body. After the initial wave peak was generated, the impact zone spread outwards, which resulted in the first wave. In this study, by directly measuring the first wave height of a landslide-generated wave, the energy conversion rate of a landslide body into the water was converted, and the influence law of the width, height, and water entry speed of the landslide body on the first wave height of landslide-generated waves was analysed; in addition, a direct measurement of the height of landslide-impulse waves was performed using an ultrasonic wave acquisition analyser.

3.1. Operating Condition. Combined with the test design and conditions, a single-factor scheme was used in the model test. The depth of water was $0.74 \mathrm{~m}$; this study examined the accuracy and stability of the data through a repetitive procedure. Four experiments were performed for each group, the first to determine the position of the initial impulse-wave peak and fix the wave gauges and the others to acquire the height of leading waves. Subsequently, their averaged value was calculated as the experimental value of the leading wave of the group. The specific operating conditions are shown in Table 2.

3.2. Experimental Verification. To verify the reliability of the model test, we compared the water level at different moments after the landslide slid into the water along the chute with the test results of Heinrich [16]. The results were the

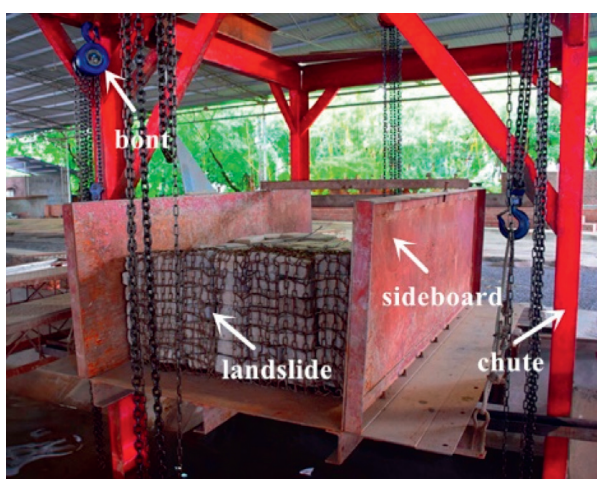

FIgURE 2: Landslide generator.

TABle 1: Size of the block.

\begin{tabular}{lccc}
\hline Type & Length $(\mathrm{cm})$ & Width $(\mathrm{cm})$ & Height $(\mathrm{cm})$ \\
\hline $\mathrm{D}_{100}$ & 18 & 12 & 6 \\
$\mathrm{D}_{80}$ & 12 & 8 & 4 \\
$\mathrm{D}_{60}$ & 9 & 6 & 3 \\
$\mathrm{D}_{40}$ & 6 & 4 & 2 \\
$\mathrm{D}_{10}$ & 3 & 2 & 1 \\
\hline
\end{tabular}

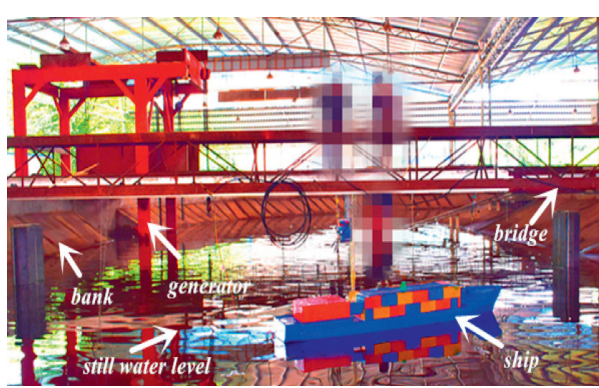

FIGURE 3: River channel. 
TABLE 2: Operating conditions.

\begin{tabular}{|c|c|c|c|}
\hline Scenario & Angle $\left({ }^{\circ}\right)$ & Length $(\mathrm{m}) \times$ width $(\mathrm{m}) \times$ height $(\mathrm{m})$ & Water velocity $(\mathrm{m} / \mathrm{s})$ \\
\hline 1 & \multirow{3}{*}{$20 / 40 / 60$} & $1 \times 0.5 \times 0.2$ & - \\
\hline 2 & & $1 \times 1.0 \times 0.2$ & - \\
\hline 3 & & $1 \times 1.5 \times 0.2$ & - \\
\hline 4 & \multirow{3}{*}{$20 / 40 / 60$} & $1 \times 0.5 \times 0.2$ & - \\
\hline 5 & & $1 \times 0.5 \times 0.4$ & - \\
\hline 6 & & $1 \times 0.5 \times 0.6$ & - \\
\hline 7 & & $1 \times 0.5 \times 0.2$ & \multirow{6}{*}{$3.66 / 5.02 / 5.83$} \\
\hline 8 & & $1 \times 0.5 \times 0.4$ & \\
\hline 9 & & $1 \times 1.0 \times 0.2$ & \\
\hline 10 & - & $1 \times 1.0 \times 0.4$ & \\
\hline 11 & & $1 \times 1.5 \times 0.2$ & \\
\hline 12 & & $1 \times 1.5 \times 0.4$ & \\
\hline
\end{tabular}

same as those in the references. Therefore, the model test established in this study can accurately simulate the physical characteristics of landslide-generated waves. The comparison results are presented in Figure 4.

3.3. Influence of Landslide Width on the Height of the First Wave of Landslide-Generated Waves. To better analyse the influence of the height of the landslide body on the height of the first wave of the landslide-generated wave, we selected the experimental water depth as $0.74 \mathrm{~m}$. The entry angles of the landslide body were $20^{\circ}, 40^{\circ}$, and $60^{\circ}$. The length of the landslide was $1 \mathrm{~m}$; the height was $0.2 \mathrm{~m}$; and the widths were $0.5,1.0$, and $1.5 \mathrm{~m}$, respectively. The influence of the width of the landslide body on the first wave height of the landslidegenerated wave is shown in Figure 5.

As shown in Figure 5, when the water depth was $0.74 \mathrm{~m}$, the first wave height of the landslide-generated wave increased with the increase in the width of the landslide body. However, the wave height resulting from the landslide with a width of $1.5 \mathrm{~m}$ was smaller than that resulting from the landslide with a width of $1.0 \mathrm{~m}$. The landslide spread to both sides during the sliding, but owing to the restrictions of the chute that could not diffuse to both sides due to the friction of the chute, the sliding speed of the landslide on both sides of the block was lower than that in the middle part. In other words, the middle of the landslide fell into the river, and part of the energy was offset, thus producing the above results. The landslide body of $1 \mathrm{~m} \times 1 \mathrm{~m} \times 0.2 \mathrm{~m}$ and $1 \mathrm{~m} \times 1.5 \mathrm{~m} \times 0.2 \mathrm{~m}$ slid into the water, and the height of the first wave of the landslide-generated wave had a slight difference and was significantly greater than that of the landslide body of $1 \mathrm{~m} \times 0.5 \mathrm{~m} \times 0.2 \mathrm{~m}$ after entering the water.

3.4. Influence of Slope Body Height on the Height of the First Wave of Landslide-Generated Wave. In the experiment process, the experimental water depth was selected as $0.74 \mathrm{~m}$. The entry angles of the landslide body were $20^{\circ}, 40^{\circ}$, and $60^{\circ}$. The length of the landslide was $1 \mathrm{~m}$; the width was $0.5 \mathrm{~m}$; and the heights were $0.2,0.4$, and $0.6 \mathrm{~m}$, respectively. The influence of the height of the landslide body on the height of the first wave of the landslide-generated wave is shown in Figure 6.

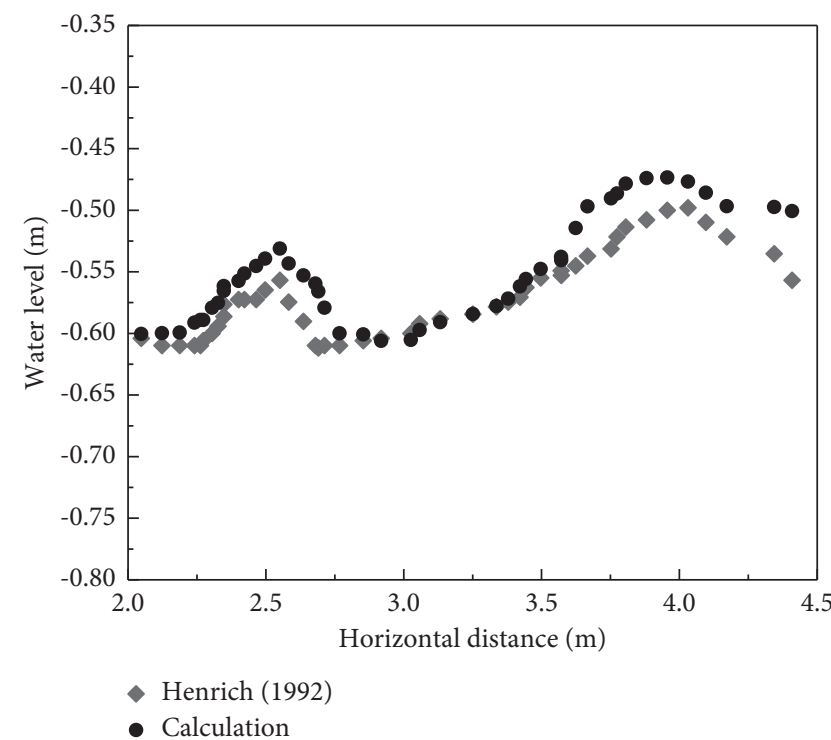

Figure 4: Comparison of the free surface of Heinrich and our model at $t=1.5 \mathrm{~s}$.

3.5. Influence of Water Entry Velocity on the Height of the First Wave of Landslide-Generated Waves. To analyse the influence of the water entry velocity on the height of the first wave of landslide-generated waves, we adopted the control variable method in the experiment. We selected a depth of $0.74 \mathrm{~m}$; water speeds of $3.66,5.02$, and $5.83 \mathrm{~m} / \mathrm{s}$; and volumes of the landslide of $0.1,0.2,0.3,0.4$, and $0.6 \mathrm{~m}^{3}$. The maximum height of the first wave of the landslide-generated wave at different water entry velocities is shown in Figure 7.

As shown in Figure 7, when the widths of the landslide body were 0.5 and $1.5 \mathrm{~m}$, the height of the first wave of the landslide-generated wave increased with the increase in the water entry velocity. When the width of the landslide body was $1.0 \mathrm{~m}$, the height of the first wave of the landslidegenerated wave first increased and then decreased. The larger the volume of the landslide and the higher the water entry velocity, the higher the height of the head wave. The maximum monitoring point of the model experiment was $18.5 \mathrm{~cm}$. 


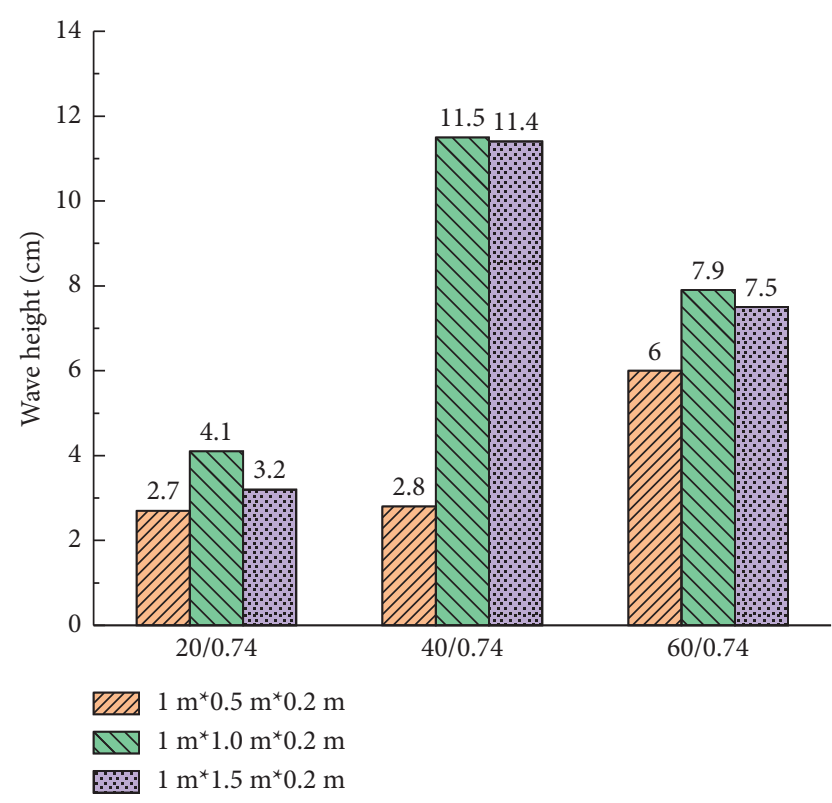

FIGURE 5: Influence of width of a landslide body on the height of the head wave of a landslide-generated wave.

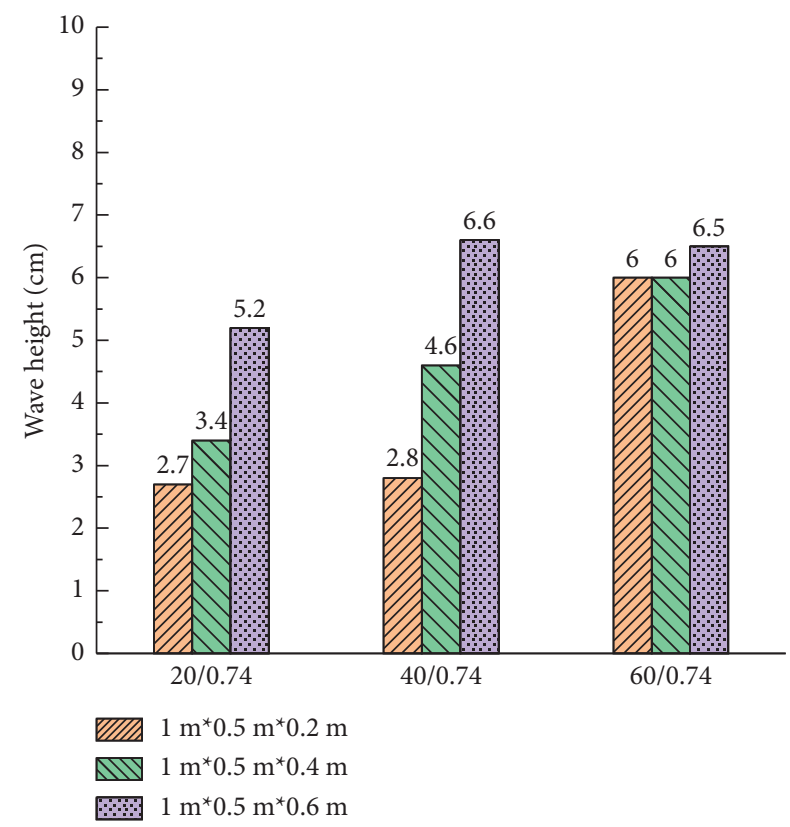

FIGURE 6: Influence of slope body height on the height of the head wave of landslide-generated waves.

\section{Formula Derivation for the Height of the First Wave of the Landslide-Generated Wave}

In this study, 150 groups of large-scale three-dimensional physical model tests were used for comprehensive analysis. The height of the first wave of the landslide-generated wave was primarily affected by the geometric characteristics of the landslide body, water entry velocity, water entry angle, and depth of the reservoir area. In this study, the length of the landslide body was set as $1 \mathrm{~m}$, and the calculation formula for

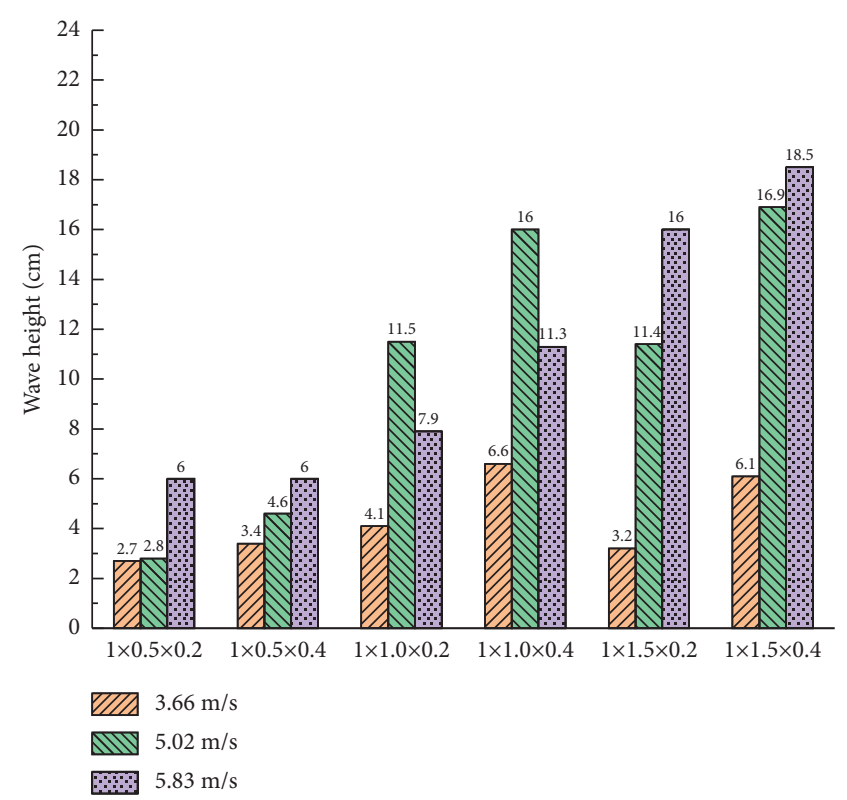

FIGURE 7: Influence of water entry velocity on the height of the head wave of landslide-generated waves.

the height of landslide-generated waves in the Three Gorges Reservoir Region was deduced through multiple regression analysis:

$$
H_{F W}=f(v, h, s, b) .
$$

In this formula, $H_{F W}$ is the height of the landslidegenerated wave, $v$ is the velocity of the landslide entering water, $h$ is the depth of the landslide entering water, $b$ is the width of the landslide, and $s$ is the height of the landslide.

In this experiment, the width of the landslide was the main control parameter. The height of the first wave of the landslide-generated wave and its influence were dimensionless, and the corresponding formulas were deduced.

$$
\frac{H_{F W}}{b}=f\left(\frac{v^{2}}{g b}, \frac{h}{b}, \frac{s}{b}\right) .
$$

In this study, the linear, exponential, logarithmic, and power functions were selected for analysis through a multiple regression analysis method, and the empirical formula of landslide surge height was deduced as follows:

$$
\begin{aligned}
\frac{H_{F W}}{b}= & 0.083-0.058 \frac{h}{b}+0.077 \frac{s}{b}+0.014 \frac{v^{2}}{g b}, \\
\frac{H_{F W}}{b}= & 0.092 e^{\left(-0.587 h / b+0.687 s / b+0.117 v^{2} / g b\right)}, \\
\frac{H_{F W}}{b}= & 0.093-0.078 \operatorname{In}\left(\frac{h}{b}\right) \\
& +0.043 \operatorname{In}\left(\frac{s}{b}\right)+0.050 \operatorname{In}\left(\frac{v^{2}}{g b}\right),
\end{aligned}
$$




$$
\frac{H_{F W}}{b}=0.092\left(\frac{h}{b}\right)^{-0.79}\left(\frac{s}{b}\right)^{0.445}\left(\frac{v^{2}}{g b}\right)^{0.471}
$$

Through a comparative analysis of the above four formulas, an accuracy comparison table of the empirical formula for the height of the first wave of the landslidegenerated wave was obtained (Table 3 ).

As shown in Table 3, formula (6) had a high accuracy, reasonable average relative error, and residual square. Therefore, formula (6) was selected as the empirical formula for the height of the head wave of landslide-generated waves.

\section{Ship Roll Motion Equation in the Area of Landslide-Generated Wave}

During the experiment, the rolling motion characteristics of the ship in the water area of landslide-generated waves were studied through large-scale physical model experiments and theoretical analysis, and the equation of ship roll motion in the area of landslide-generated waves was constructed.

5.1. Roll Moment of Inertia. In this study, the method of the radius of inertia was used to calculate the rolling moment of inertia and the additional moment of inertia, which are expressed as follows:

$$
I_{x x}+J_{x x}=\frac{D}{g} K_{\varphi \varphi}^{2}
$$

where $D=0.01015 t, g=9.8 \mathrm{~m} / \mathrm{s}^{2}$, and $K_{\varphi \varphi}=0.08$.

5.2. Roll-Damping Moment. Nonlinear factors exist in the rolling motion. To facilitate the calculation, when the angle of the ship roll is small, the damping moment and restoring moment can be equivalently linearised. The square model adopted in this study was as follows:

$$
M(\dot{\phi})=-B \dot{\phi}|\dot{\phi}| \text {. }
$$

5.3. Rolling Recovery Moment Coefficient. Based on the calculation formula of the righting arm proposed in the study of stability at large inclination angles,

$$
G Z=y_{B} \cos \varphi-\left(z_{G}-z_{B}\right) \sin \varphi,
$$

where $y_{B}$ is the horizontal coordinate of the ship's buoyant centre, $z_{B}$ is the vertical coordinates of the ship's buoyant centre, and $z_{G}$ is the vertical height of the ship's gravity centre.

5.4. Equation of Ship Roll Motion. Through the calculation of the ship's centre coordinate, ship's initial stability, ship's rolling natural period and frequency, wave angular frequency, rolling moment of inertia, rolling damping moment, rolling recovery moment coefficient, and other parameters, the rolling motion equation of the ship was established. The details are as follows:
TABle 3: Accuracy comparison table of the empirical formula for the height of the head wave of landslide-generated waves.

\begin{tabular}{lcccc}
\hline Statistical target & $(3)$ & $(4)$ & $(5)$ & $(6)$ \\
\hline Average relative error (\%) & 36 & 40 & 29 & 33 \\
Residual sum of squares & 0.081 & 0.088 & 0.053 & 0.058 \\
\hline
\end{tabular}

$$
I_{x x}^{\prime} \ddot{\phi}+B|\dot{\phi}| \dot{\phi}+C_{1} \varphi+C_{3} \varphi^{3}=D h \alpha_{e o} \sin \omega_{e} t .
$$

\section{Ship Manoeuvring Motion Characteristics in Landslide-Generated Waves}

By establishing the equation of ship roll motion in landslidegenerated wave areas as described in the previous section, the manoeuvrability of the ship in still water was simulated and analysed, and the ship's manoeuvrability was predicted through a numerical simulation. The main parameters of the ship are listed in Table 4.

6.1. Z-Manoeuvre Tests. Z-manoeuvre tests can be used to measure the manoeuvring performance of ships to evaluate their course change performance. This study verified the correctness and reliability of the model through z-manoeuvre tests of a ship in still water. The $\mathrm{z}$-manoeuvre tests of ships in still water are shown in Figure 8.

6.2. Ship Trajectories at Different Speeds. In this study, by establishing the ship manoeuvring motion equation, the changing law of ship trajectories through the landslide section at 9,15 , and $21 \mathrm{~km} / \mathrm{h}$ was analysed. During the simulation, the ship maintained a zero rudder angle. The details are shown in Figure 9.

As shown in Figure 9, when the ship sails to the landslide section, landslides occur. The landslide-generated wave interacts with the ship, resulting in a large lateral displacement of the ship. Under the continuous action of landslide-generated waves, if the ship does not perform emergency manoeuvres, the lateral displacement of the ship will gradually increase, eventually resulting in a collision between the ship and a hydraulic structure, such as the bank slope and wharf, resulting in a significant loss of life and property. Figure 9 also shows that when the ship sails at different speeds, its sailing tracks do not coincide because of the lateral action of the landslide-generated wave. Flow velocity is the main factor affecting the torque, and the torque increases with an increase in the speed of the ship. The greater the speed of the ship, the greater the velocity of the flow field around the ship, and the greater the torque of the torsional ship, resulting in a greater lateral offset. Therefore, if the ship encounters landslide-generated waves during sailing, the crew should reduce the sailing speed and the distance of the ship to the right, thus reducing the risk of collision between the ship and the bank slope and wharf. Additionally, reducing the speed of the ship can also reduce the risk of collision with an opposite ship and improve the safety of ship navigation. 
Table 4: Parameters of the ship.

\begin{tabular}{|c|c|c|c|}
\hline Parameter & & Actual ship & \\
\hline Ship length (m) & & 94.5 & \\
\hline Ship beam $(\mathrm{m})$ & & 15.1 & \\
\hline Ship depth (m) & & 9.0 & \\
\hline Draught $(\mathrm{m})$ & & 5.6 & \\
\hline Block coefficient & & 0.7 & \\
\hline Prismatic coefficient & & 0.69 & \\
\hline Weight $(t)$ & & 3500 & \\
\hline Area of rudder $\left(\mathrm{m}^{2}\right)$ & & 14.3 & \\
\hline Height of rudder (m) & & 4.1 & \\
\hline Aspect ratio & & 1.72 & \\
\hline Number of blades & & 4 & \\
\hline Diameter of propeller $(\mathrm{m})$ & & 3.1 & \\
\hline Screw pitch $(\mathrm{m})$ & & 2.6 & \\
\hline Forward draft (m) & & 4.4 & \\
\hline Aft draft (m) & & 6.8 & \\
\hline Buoyancy coordinates $(\mathrm{m})$ & & 0.88 & \\
\hline Height of centre of gravity $(\mathrm{m})$ & & 4.2 & \\
\hline Transverse metacentric height (m) & & 8.63 & \\
\hline Navigational speed $(\mathrm{km} / \mathrm{h})$ & 9 & 15 & 21 \\
\hline Revolving speed (r/min) & 112 & 154 & 198 \\
\hline
\end{tabular}

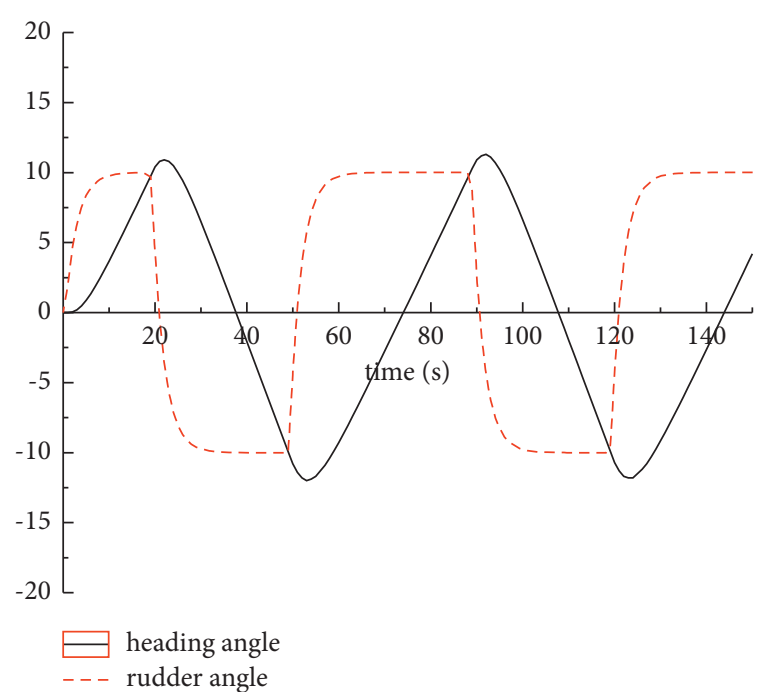

FIgURE 8: $\mathrm{Z}$ model experiment of a ship.

\subsection{Characteristics of Ship Emergency Manoeuvring in Inclined Waves}

6.3.1. Characteristics of Ship Emergency Manoeuvring in Inclined Waves of $22^{\circ}$. During the ship's sailing, a landslide occurred at the left front end, resulting in landslide-generated waves. Landslide-generated waves propagated up and down the river and acted on the left front of the hull. This section primarily studies the characteristics of ship emergency manoeuvring under the action of landslide-generated waves in inclined waves of $22^{\circ}$.

As shown in Figure 10, when the ship sailed forward at a certain speed, the landslide-generated wave caused the ship to drift to the right. When the ship moved $100 \mathrm{~m}$ horizontally to the right, the ship left full rudder, and the force

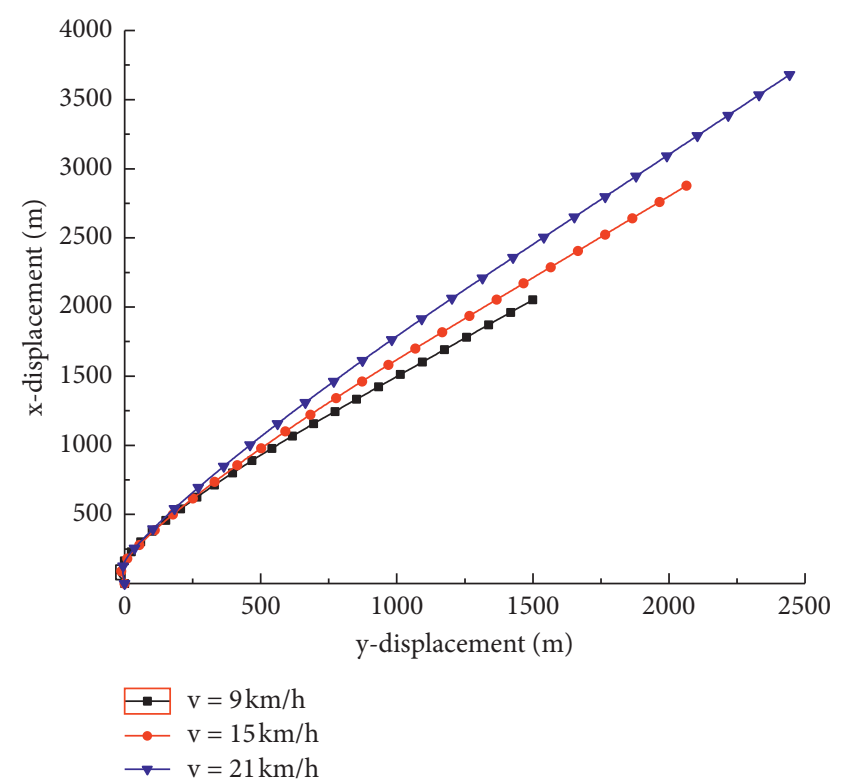

FIGURE 9: Turning trajectory of a ship under different navigational speeds in a landslide-induced wave.

acting on the rudder blade could be decomposed into the resistance and lift of the rudder, in which the resistance occurred along the direction of fluid flow, and the rudder lift was perpendicular to the direction of flow. The rudder lift relative to the middle of the ship produced a steering moment which caused the ship to turn, and there was a certain reaction time. Instead of sailing to the left at $100 \mathrm{~m}$ horizontally, it continued to drift to the right, with a maximum horizontal drift of $117.7 \mathrm{~m}$. During a full rudder operation, the ship returned to its initial track. Under the same external environment, when the ship's sailing speed was 9, 15, and $21 \mathrm{~km} / \mathrm{h}$, the maximum horizontal righthand distance of the 


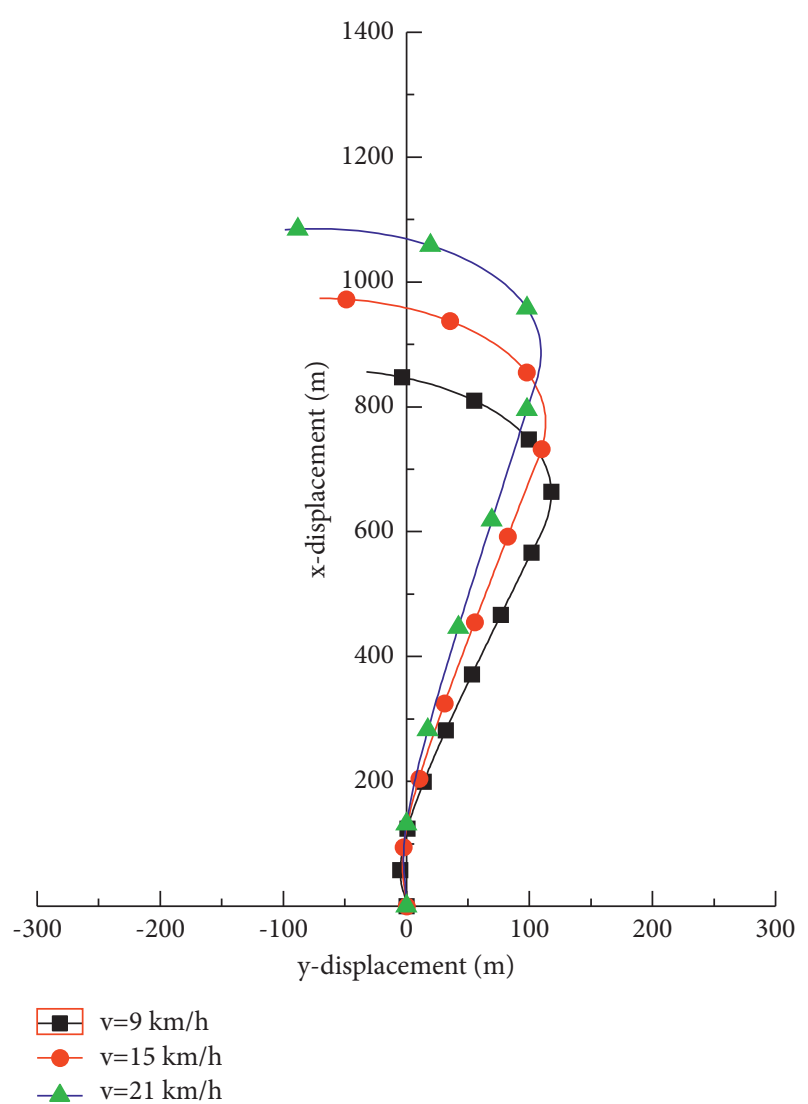

Figure 10: Turning trajectory of ship at $100 \mathrm{~m}$ full rudder condition.

ship was $117.7,113.2$, and $109.4 \mathrm{~m}$ respectively. The faster the ship sailed, the sooner the ship turned to the track line with a full rudder. However, the forward sailing distance of the ship was larger, with a maximum value of $1085.3 \mathrm{~m}$.

As shown in Figure 11, when the ship moved $200 \mathrm{~m}$ horizontally to the right, the ship turned left at full rudder, and there was a certain reaction time. When the ship's sailing speed was $9 \mathrm{~km} / \mathrm{h}$, the horizontal rightward distance of the ship was $218.3 \mathrm{~m}$. The sailing speed of the ship was $15 \mathrm{~km} / \mathrm{h}$, and the maximum distance of the ship to the right was $213 \mathrm{~m}$. When the ship travels $1484.1 \mathrm{~m}$ forward, the track line intersected the initial course. When the ship travelled at $21 \mathrm{~km} / \mathrm{h}$, the maximum distance of the ship to the right horizontally was $210.5 \mathrm{~m}$, and the ship travelled $1712.3 \mathrm{~m}$ forward, the track line intersected the initial course.

6.3.2. Characteristics of Ship Emergency Manoeuvring in Inclined Waves of $169^{\circ}$. During the sailing of the ship, the entry point of the landslide was behind the ship on the left. The entry point of the landslide was the centre of the circle for the landslide-generated wave, from which it had scattering propagation. The landslide-generated wave in this section had a diagonal incident at $169^{\circ}$ and acted on the left rear of the ship. The manoeuvring characteristics of ships with a rightward deviation of 100 and $200 \mathrm{~m}$ were studied.

As shown in Figures 12 and 13, the ship sailed at different speeds in the river, and the landslide-generated

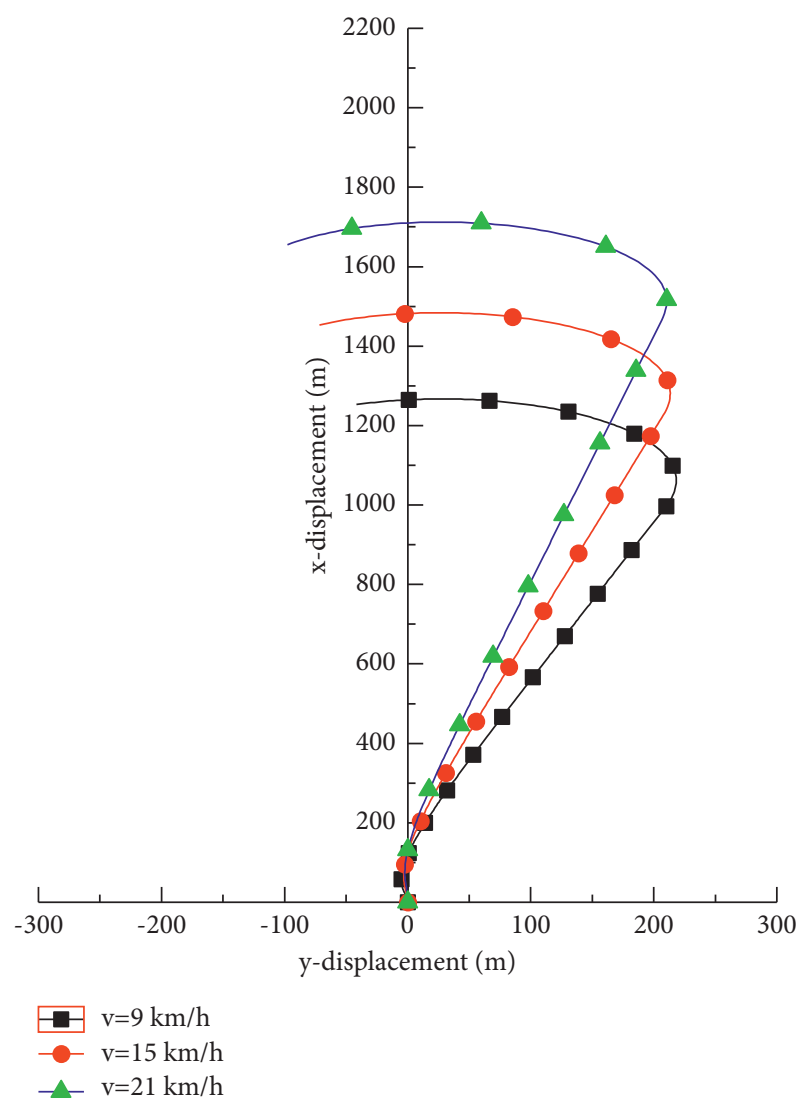

Figure 11: Turning trajectory of ship at a $200 \mathrm{~m}$ full rudder condition.

wave acted on the left rear of the ship, resulting in a certain deviation of the ship. When the ship moved to the right for $100 \mathrm{~m}$ and turned full rudder to the left, it continued to drift to the right for a certain distance, with a maximum deviation of $109.3 \mathrm{~m}$. In the turning stage, with an increase in the rudder angle, a horizontal force and moment were generated, resulting in transverse and angular acceleration. The ship maintained the original straight motion at this stage. In the transition stage, transverse and angular acceleration both existed and changed constantly. At the beginning of the transition stage, the centre of gravity of the ship tended to move to the opposite side of the rudder, and the ship began to enter the rotating motion state. As shown in Figure 12, when the ship's sailing speed was 9, 15 , and $21 \mathrm{~km} / \mathrm{h}$, its horizontal righthand distance was $109.3,106.1$, and $104.3 \mathrm{~m}$, respectively. Figure 13 shows that the ship was affected by the landslide-generated wave and had a rightward deviation. When the ship was offset by $200 \mathrm{~m}$ to the right and turned full rudder to the left and when the ship's sailing speed was 9,15 , and $21 \mathrm{~km} / \mathrm{h}$, its distance to the right was 209.6, 206.2, and $204.5 \mathrm{~m}$, respectively.

6.4. Characteristics of Ship Emergency Manoeuvring in Transverse Waves. If a sudden landslide-generated wave occurs during sailing, the ship should adopt emergency 


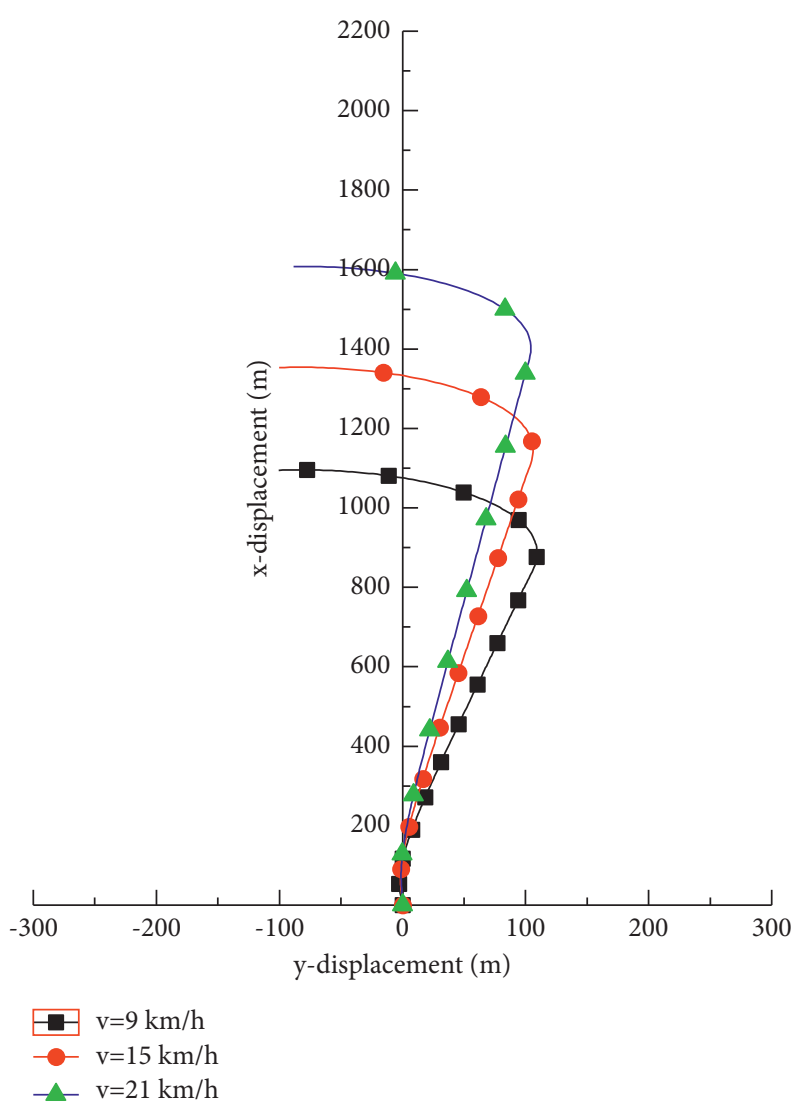

FIGURE 12: Turning trajectory of ship at a $100 \mathrm{~m}$ full rudder condition.

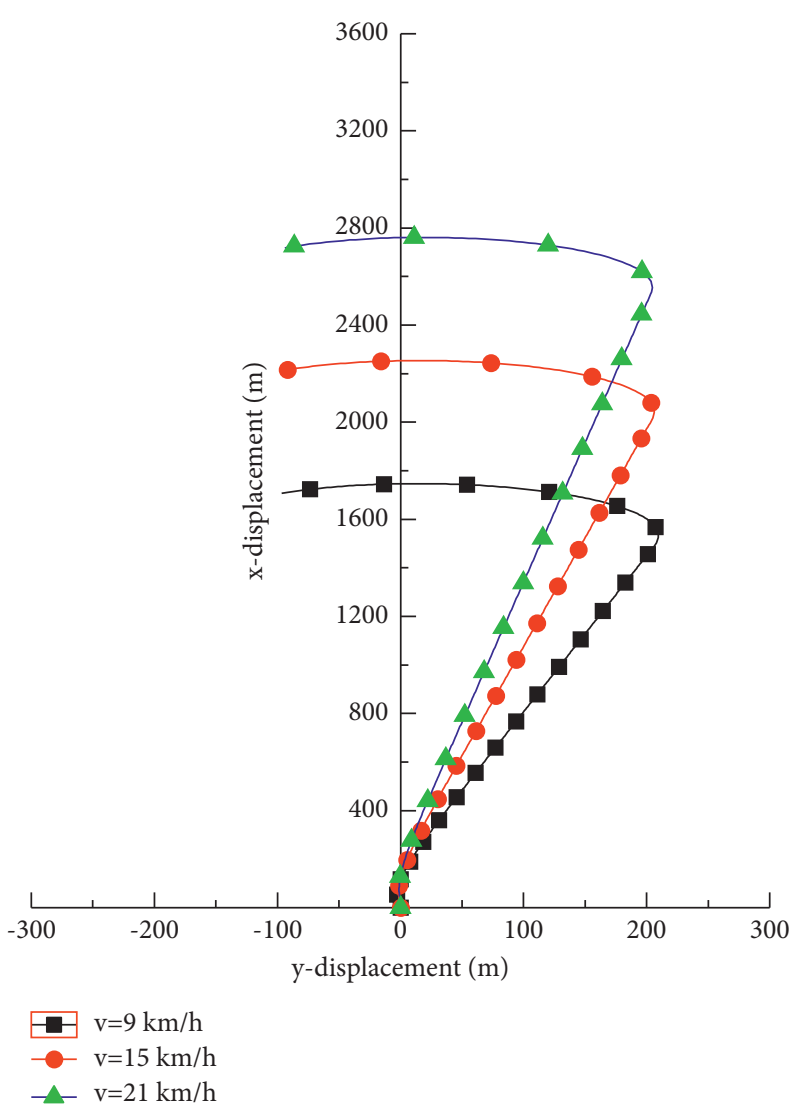

Figure 13: Turning trajectory of ship at a $200 \mathrm{~m}$ full rudder condition. 


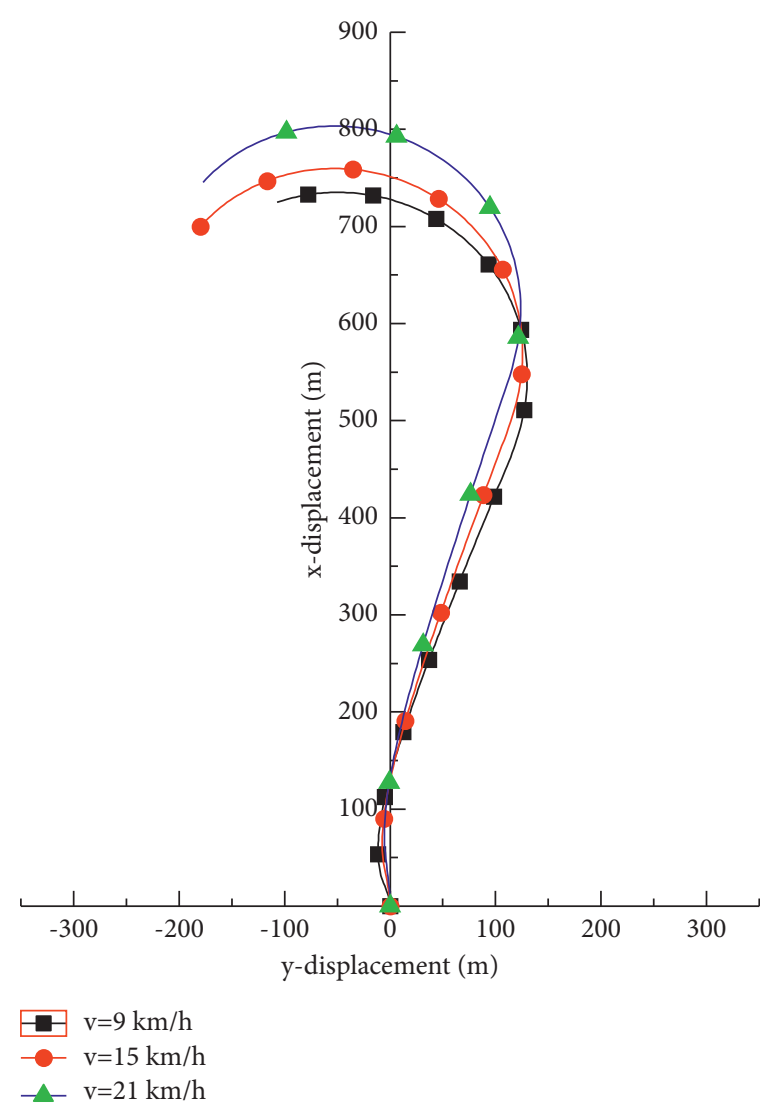

FIgURE 14: Turning trajectory of a ship under the condition of full rudder at a left transverse wave at $100 \mathrm{~m}$.

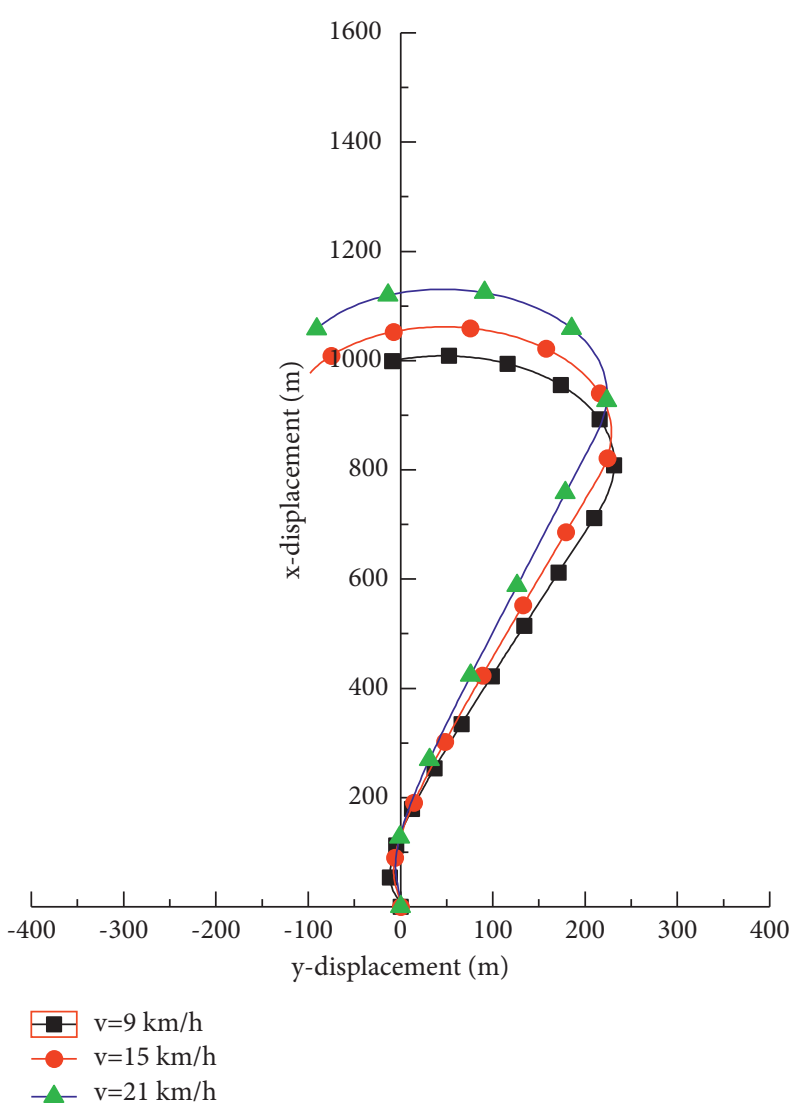

FIgURE 15: Turning trajectory of a ship under the condition of full rudder at a left transverse wave at $200 \mathrm{~m}$. 
manoeuvring techniques. This section primarily studies the horizontal drift of the ship under the interaction between the landslide-generated wave and a ship sailing at different speeds and then proposes the risk response methodology under active full rudder at different positions.

As shown in Figure 14, the ship may collide with the wharf or bank slope without any manipulation during the drifting process. Therefore, in the actual navigation process, the ship should be in the appropriate position of the rudder. The ship deviated to the right by $100 \mathrm{~m}$ and turned full rudder to the left. When a ship sails in the area of landslideinduced waves, the instantaneous wet surface area of the hull changes dramatically, and wave diffraction and radiation are relatively complex, resulting in nonlinear properties and in a wave drift force, which affects and changes the original course of the ship. The ship then has a certain reaction time. Instead of sailing to the left at a horizontal position of $100 \mathrm{~m}$, it continued to deviate to the right, and the maximum horizontal deviation was $130 \mathrm{~m}$. Ship steering began to take effect when the ship was at its maximum deviation to the right. The ship began to sail to the left with a full rudder and returned to the track line within a certain time. The figure also shows that, under the same external environment, when the ship's sailing speed was 9,15 , and $21 \mathrm{~km} / \mathrm{h}$, the maximum horizontal right and distance generated by the ship was 130 , 125.7 , and $123.8 \mathrm{~m}$, respectively.

As shown in Figure 15, the maximum horizontal deviation was $231.5 \mathrm{~m}$ when the ship shifted to the right by $200 \mathrm{~m}$ and turned full rudder to the left. Under the same external environment, the ship's sailing speed was 9,15 , and $21 \mathrm{~km} / \mathrm{h}$, and the maximum horizontal distance to the right generated by the ship was $231.5,228.6$, and $223.8 \mathrm{~m}$, respectively.

\section{Conclusion}

This study integrated typical rock landslide parameters and fracture development in the Three Gorges Reservoir Region, and the design of a three-dimensional physical model experiment on landslide-generated waves based on the similarity criterion. In this paper, the influences of the width, height, and entry speed of the landslide body on the height of the first wave of landslide-generated waves are comprehensively explained, and an empirical formula for the height of the first wave of landslide-generated waves in the curved section of a mountain river is deduced. Additionally, based on a large-scale three-dimensional physical model experiment, the ship's rolling motion equation in the water area of landslide-generated waves is derived for the first time. Subsequently, the characteristics of ship manoeuvrability in an area of landslide-generated waves are studied, which fills the gap in the theoretical research on the coupling effect between three-dimensional landslide-generated waves and ships. The main conclusions are as follows:

(1) In the curved section of the Three Gorges Reservoir Region, the height of the first wave of the landslidegenerated wave increases with an increase in the width and height of the landslide body and the water entry velocity.
(2) An empirical formula for the height of the first wave of landslide-generated waves in the curved section of the Three Gorges Reservoir Region is derived using a multiple regression analysis method. Through comparative analysis, the empirical formula was proven to have high precision and veracity.

(3) When the ship encounters the lateral action of landslide-generated waves, the ship's sailing track does not coincide at different speeds. The greater the ship's sailing speed, the greater its lateral deviation, and the greater its movement distance in the direction of sailing.

(4) The landslide-generated wave action causes the ship to move horizontally to the right by $100 \mathrm{~m}$, and the ship turns full rudder to the left; thus, it has a certain delay time. Instead of travelling to the left at $100 \mathrm{~m}$ horizontally, it continues to the right. When the ship's sailing speed is $9 \mathrm{~km} / \mathrm{h}$, the maximum horizontal deviation is $130 \mathrm{~m}$. When the ship's sailing speed is $21 \mathrm{~km} / \mathrm{h}$, the ship turns to the track line earlier under the full rudder condition, and the maximum sailing distance of the ship is $1085.3 \mathrm{~m}$.

\section{Data Availability}

The data presented in this study are available from the corresponding author upon request.

\section{Conflicts of Interest}

The authors declare that there are no conflicts of interest.

\section{Acknowledgments}

This study was financially supported by the National Natural Science Foundation (51479015), the Social Science and Technology Innovation Program for People's Livelihood in Chongqing (cstc2019ngzx0017, cstc2020jscx-lyjsAX0009, and cstc2019jscx-lyjsAX0008), and the Science and Technology Program of the Chongqing Education Commission (KJQN201900735).

\section{References}

[1] D. M. Duc, D. Q. Khang, D. M. Duc et al., "Analysis and modeling of a landslide-induced tsunami-like wave across the Truong river in Quang Nam province, Vietnam," Landslides, vol. 17, no. 10, pp. 2329-2341, 2020.

[2] H. Ersoy, M. Karahan, K. Gelisli et al., "Modelling of the landslide-induced impulse waves in the Artvin Dam reservoir by empirical approach and 3D numerical simulation," Engineering Geology, vol. 249, pp. 112-128, 2018.

[3] S.-C. Hsiao, M.-Y. Shih, and N.-J. Wu, "Simulation of propagation and run-up of three dimensional landslide-Induced Waves Using a Meshless Method," Water, vol. 10, no. 5, 2018.

[4] M. Karahan, H. Ersoy, and A. Akgun, "A 3D numerical simulation-based methodology for assessment of landslidegenerated impulse waves: a case study of the Tersun Dam reservoir (NE Turkey)," Landslides, vol. 17, no. 12, pp. 2777-2794, 2020. 
[5] R.-S. Shih, W. Weng, and C. Li, "Experimental study on the generation and attenuation of landslide tsunamis," Journal of Coastal Research, vol. 34, no. 4, pp. 864-876, 2018.

[6] G.-B. Kim, W. Cheng, S. Richards et al., "Three dimensional landslide generated tsunamis: numerical and physical model comparisons," Landslides, vol. 17, no. 5, pp. 1145-1161, 20 !9.

[7] G. K. Bullard, R. P. Mulligan, and A. Carreira, "Experimental analysis of tsunamis generated by the impact of landslides with high mobility," Coastal Engineering, vol. 152, no. 1, 2019.

[8] T. Takabatake, M. Mall, D. C. Han et al., "Physical modeling of tsunamis generated by subaerial, partially submerged, and submarine landslides," Coastal Engineering Journal, vol. 62, no. 4 , pp. $582-601,2020$.

[9] G. Chillcce and O. Moctar, "A numerical method for manoeuvring simulation in regular waves," Ocean Engineering, vol. 170, pp. 434-444, 2018.

[10] G. Taimuri, J. Matusiak, T. Mikkola, P. Kujala, and S. Hirdaris, "A 6-DoF maneuvering model for the rapid estimation of hydrodynamic actions in deep and shallow waters," Ocean Engineering, vol. 218, Article ID 108103, 2020.

[11] M. A. A. Hasnan, H. Yasukawa, N. Hirata, D. Terada, and A. Matsuda, "Study of ship turning in irregular waves," Journal of Marine Science and Technology, vol. 25, no. 3, pp. 1024-1043, 2020

[12] M. G. Seo and Y. Kim, "Numerical analysis on ship maneuvering coupled with ship motion in waves," Ocean Engineering, vol. 38, no. 17-18, pp. 1934-1945, 2011.

[13] A. Carchen, S. Turkmen, B. Piaggio, W. Shi, N. Sasaki, and M. Atlar, "Investigation of the manoeuvrability characteristics of a Gate Rudder system using numerical, experimental, and full-scale techniques," Applied Ocean Research, vol. 106, Article ID 102419, 2021.

[14] H. Yasukawa and Y. Yoshimura, "Introduction of MMG standard method for ship maneuvering predictions," Journal of Marine Science and Technology, vol. 20, no. 1, pp. 37-52, 2015.

[15] R. Suzuki, Y. Tsukada, and M. Ueno, "Estimation of full-scale ship manoeuvrability in adverse weather using free-running model test," Ocean Engineering, vol. 213, Article ID 107562, 2020.

[16] P. Heinrich, "Nonlinear water waves generated by submarine and aerial landslides," Journal of Waterway Port Coastal and Ocean Engineering, vol. 118, pp. 223-238, 1992. 